ZISWAF : Jurnal Zakat danWakaf

E-ISSN 2654-8569, P-ISSN 2654-8577
Volume 8 Number 1 Year 2021

Page 18 - 33

\title{
INTEGRATION OF SHARIA IN ZAKAT LAW
}

\author{
Aristoni \\ Faculty of Sharia, State Islamic Institute of Kudus, Kudus
}

\begin{abstract}
Law No. 23 of 2011 on Zakat Management, which is abbreviated as the Law of Zakat Management, places Islamic law as a principle for the management of zakat, so every zakat amil in the planning, application, and coordination of collection and allocation of resources must always be based on the regulations of Islamic law. The aim of this article is to explain the existence of zakat in Islamic law and the law on the management of zakat, Law No. 23 of 2011 as an ius constitutum, and integrating Islamic law in the law of zakat management. This article can be categorized as a type of library research. The method used was a qualitative approach. Besides a qualitative approach, a normative legal approach is also used in the discussion of this article. The data source used was secondary data, comprising primary legal materials, secondary legal materials, and tertiary judicial materials. The results of the study show that the existence of zakat in Islamic law and the law of zakat management are important pillars in building the values of devotion to Allah SWT, justice, and community welfare. The passage of Law No. 23 of 2011 is an inseparable part of the current national legal system (ius constitutum) and integrating Islamic law in the law of zakat management is reflected in the preamble and in Clause 2 of Law No. 23 of 2011, which lay down Islamic law as a principle for the management of Zakat.
\end{abstract}

Keywords: Islamic Law;Zakat; Ius Constitutum; Zakat Management

*Corresponding author: aristoni@iainkudus.ac.id

Received: December 11, 2020; Accepted: May 05, 2021; Published: June 15, 2021

Abstrak: Undang-Undang Nomor 23 Tahun 2011 tentang Pengelolaan Zakat yang selanjutnya disingkat Undang-Undang Pengelolaan Zakat menempatkan syariat Islam sebagai asas dalam pengelolaan zakat, ini berarti bahwa setiap amil zakat dalam menjalankan perencanaan, pelaksanaan, dan pengoordinasian dalam pengumpulan, pendistribusian, dan pendayagunaan harus mendasarkan pada ketentuan syariat Islam. Penulisan artikel ini bertujuan untuk menjelaskan keberadaan zakat dalam hukum Islam dan Undang-Undang Pengelolaan Zakat, Undang-Undang Nomor 23 Tahun 2011 sebagai ius constitutum, dan integrasi syariah dalam Undang-Undang Pengelolaan Pengelolaan Zakat. Artikel ini dapat dikategorikan sebagai jenis penelitian kepustakaan. Metode pendekatan yang digunakan adalah pendekatan kualitatif. Selain pendekatan kualitatif, dalam pembahasan artikel ini juga menggunakan pendekatan yuridis normatif. Sumber data yang digunakan berupa data sekunder yang terdiri dari bahan hukum primer, bahan hukum sekunder, dan bahan hukum tersier. Hasil kajian menunjukkan bahwa keberadaan zakat dalam hukum Islam maupun Undang-Undang Pengelolaan Zakat menjadi pilar 
penting dalam membangun nilai-nilai pengabdian kepada Allah SWT, mewujudkan keadilan dan kesejahteraan masyarakat. Disahkannya Undang-Undang Nomor 23 Tahun 2011 menjadi bagian yang tak terpisahkan dari sistem hukum nasional yang berlaku sekarang ini (ius constitutum), dan integrasi syariah dalam Undang-Undang Pengelolaan Zakat tercermin dalam konsideran dan ketentuan Pasal 2 Undang-Undang Nomor 23 Tahun 2011 yang menempatkan syariat Islam sebagai asas dalam pengelolaan zakat.

Kata Kunci:Syariat Islam; Zakat; Ius Constitutum; Pengelolaan Zakat

\section{INTRODUCTION}

As one of the third pillars of Islam, zakat in Islam has a position adjacent to prayer, where not less than 28 times Allah SWT mentions the order of zakat accompanied by the order of prayer. This is understandable because the relationship between the two is important. Zakat is defined primarily as the worship of maliyah, while prayer is interpreted primarily as the worship of badaniyah (Ash-Shiddieqy, 2009).

The declaration of zakat actually has a noble purpose, that is, where Allah SWT does not want the accumulation of assets in someone's hands (Safitri, 2017).Islam emphasizes that the property owned by a Muslim has, to a certain extent, the rights of other people who ask and who do not ask, namely the rights of the poor, the rights of relatives, and the rights of those who run out of travel. In this context, Islam does not teach exclusivity in religion; therefore, every Muslim is ordered to help and love his fellow human beings, especially fellow Muslims. One of the material rights issued by Muslims is in the form of zakat (Hafidhuddin et al., 2015). The concept of zakat in Islam is not only understood as evidence of a servant's obedience in carrying out Islamic teachings but also has the goal of realizing the social justice and economic welfare of the Muslim community (Rahayu, 2018). This gives an understanding that Islam not only regulates issues of worship to Allah SWT but also pays attention to social and humanitarian problems for its people in need (Hafriza et al., 2018). Therefore, zakat in Islam is a binding obligation, which means that paying zakat for a Muslim whose property has reached a certain level (nisab) is a must (Yurista, 2017). If the obligation of zakat is not fulfilled, then other parties are harmed, namely the mustahik/asnaf or people who are entitled to receive zakat (Hafidhuddin et al., 2015).

The essence of zakat is the management of funds obtained from the aghniya to be submitted to asnafs (zakat recipients). The existence of zakat allows the distribution of income or wealth to minimize the social gap between the rich and the poor (Dahlan, 2018). The existence of zakat is also a form of practicing Islamic religious attitudes to help each other (ta'awun) and solidarity among Muslims (Mochlasin, 2014).

In the Qur'an, eight asnafs are entitled to receive zakat, including the poor, poor, amil, converts, riqab, gharimin, fisabilillah, and ibn sabil. The provision of zakat as mentioned in the Qur'an explicitly is oriented to the protection of the security of individuals and society as required in the maqasid sharia, as everyone must be safe and free from the dangers of hunger and poverty. Thus, the zakat in Islam is an important pillar that is inseparable from the life of the community, is no exception in Indonesia, and the biggest Muslims around the world have great potential for zakat. 
Based on the research results of BAZNAS, the Bogor Agricultural Institute, Islamic Development Bank quoted by Clarashinta Canggih et al. (2017) stated that the potential for national zakat is IDR 217 trillion. The potential zakat figure can be used to serve and protect residents from poverty due to the current Covid-19 disease. This is in line with the opinion of Hafidhuddin et al.(2015), who stated that zakat allocation in Islam is not only aimed at alleviating poverty, reducing social inequality, and improving people's welfare, but can also be used to overcome disease outbreaks in a country. To realize the role and function of zakat to run optimally in improving the welfare of society and at the same time being able to actualize such great potential, it is necessary to regulate national zakat governance through a set of legal rules.

In Indonesia, the regulation of zakat management through statutory regulations is necessary because Indonesia is a state of law. The existence of regulations regarding zakat management will provide legal protection and, at the same time, strengthen the position of the national zakat agency (BAZNAS) as a coordinator in the management of national zakat, in addition to realizing justice, benefit, and legal certainty. The importance of this law is in line with the Islamic perspective, that not every person or group of people can carry out their duties as amil zakat without a clear mandate and legality (Hafidhuddin et al., 2015). The arrangement of zakat management in Indonesia is contained in Law Number 23 of 2011 concerning Amendments to Law Number 38 of 1999 concerning Zakat Management, which is then strengthened by Government Regulation Number 14 of 2014 and Impres Number 3 of 2014 and other regulations.

The existence of Sharia principles in the Zakat Management Law, which animates each article, is an important keyword to be understood by every amil zakat. The collected zakat must be distributed and utilized according to the principles or principles of Sharia, based on the Qur'an and Hadith as a source of law. In line with these Sharia principles, Law Numbers 23 of 2011, 25, and 26 confirm that zakat must be distributed to mustahik zakat under Islamic law, and the distribution of zakat is carried out based on a priority scale by taking into account the principles of equity, justice, and territoriality. Compliance with Sharia principles in the distribution and utilization of zakat is allegedly the background of the provision whereby obtaining a permit as an Amil Zakat institution must meet the registered requirements as a social organization in Indonesia that regulates the fields of education, preaching, and social society in the form of a legal entity (Suprima \& Rahman, 2019).

The legal policy regulating zakat management as regulated in the Zakat Management Act provides direction and what should be achieved in the national zakat management system. However, this system will only be realized effectively and efficiently, and robustly if it is implemented properly and correctly following Sharia principles (siyasah syar'iyyah) by every Muslim community, especially by zakat managers, and the embodiment of Sharia principles in the management of zakat will have implications for openness and increased trust in zakat management institutions. It is important to understand that the management of zakat by the state is not an objective, but only an instrument. The real purpose is the fulfillment and distribution of zakat to those entitled to receive (Wibisono, 2015). 
Research that examines the management of zakat has been carried out both in the form of normative legal research and empirical research.Like the previous research conducted by Muhammad Aziz (2017)with the title "Zakat Management Strategies Productively at the Amil Zakat Institution in the Review of Law of the Republic of Indonesia Number 23 the Year 2011 concerning Zakat Management (Case Study at Nurul Hayat Tuban Branch Office 2015-2016)", The results of research studies show that productive zakat management at the Amil Zakat Nurul Hayat institution, Tuban Branch Office, has a positive impact in building and prospering the community, including through several activities and stages such as educational scholarship programs and independent pillar programs.Suprima and Holilur Rahman (2019) in their research entitled "Regulation of Zakat Management", results of their study show that the state has a significant role, especially in managing and prospering society supported by a set of legal rules regarding zakat.Furthermore, Puspitasari and Darma (2019) in their research by taking the location at the Amil Zakat Institute in the Special Region of Yogyakarta focused on the effect of implementing sharia governance in providing satisfaction for muzakki. The results of his research study indicate that from the hypothesis test by evaluating the value of structural model parameters, the implementation of sharia governance has a positive effect on muzakki satisfaction, and loyalty and satisfaction do not have a significant effect on muzakki loyalty.

Some of the previous research is relevant to this research, which is related to the management of zakat, but the difference is that this research is more focused on the study of how zakat exists in Islamic law and the law of zakat management, why Law No. 23 of 2011 as an ius constitutum, and how the integration of Islamic law in the law of zakat management. Therefore, this research aims to explain the existence of zakat in Islamic law and the Law of Zakat Zakat Management, Law No. 23 of 2011 as an ius constitutum, and the integration of Islamic law in the law of zakat management.

\section{RESEARCH METHODS}

This article can be categorized as a type of library research that uses a qualitative approach as its basis. A qualitative approach can be interpreted as an approach to managing and analyzing data that does not use mathematical variables, symbols, or numbers, but it does an in-depth study of the issues to be discussed (Lexi J, 2002). In the discussion, this article uses an approach normative juridical, namely, an approach using the laws and regulations in force in a country (Amiruddin \& Asikin, 2012). The statutory regulatory approach is further sharpened by a conceptual approach, namely an approach using concepts that are understood as the thoughts of experts or experts in the field of Islamic law to find common ground between principles of Islamic law and the law of zakat management.

Following this approach, the data sources used in this study were secondary data in the form of primary, secondary, and tertiary legal materials. The primary legal material is in the form of Law No. 23 of 2011 on Zakat Management and other regulations that are still related to the issues to be discussed in this study.Secondary legal materials include books, journals, magazines, and so on.Meanwhile, tertiary legal materials are materials that support primary legal materials and secondary 
legal materials, namely in the form of legal dictionaries, encyclopedias, and so on, which are still related to this research. The data collection techniques used in writing this article are based on a literature review. Furthermore, all collected data were analyzed using qualitative data analysis techniques and were descriptive in nature. The reason for using this analysis technique is to describe and analyze in a coherent, logical, and non-overlapping manner so that it can be easily understood about the integration of Islamic law in the law of zakat management.

\section{RESULTS AND DISCUSSION}

\section{The Existence of Zakat in Islamic Law and The Law of Zakat Management 1.1. The Existence of Zakat in Islamic Law}

The fact that Islam is a holy religion, revealed by the Most Holy (Allah) through the Prophet SAW with the mediator of the angel Gabriel is equivalent to the revelation of the Qur'an which is used as the main source of Islamic teachings. Islam and the Qur'an are identical, this is because all the teachings of Islam are contained in the Qur'an. In other words, the teachings of Islam are the content of the Qur'an which is strengthened by Hadith. The teachings of Islam are indeed very broad, covering all the joints of life and the needs of mankind. Sharia is the basis of Islamic teachings, which includes the fields of worship and muamalah (Khadziq, 2009).

Along with its development, the meaning of sharia experiences a narrowing of the meaning that only concerns Islamic law, as in the view of Muhammad Daud Ali as quoted by Saifudin Nur, said that sharia is the foundation of fiqh, while fiqh is a concrete formulation of Islamic law and can be applied to certain cases according to situations and conditions. Meanwhile, talking about Islamic law is Islamic law that applies throughout the ages. At this point, it can be understood that the two have different sides, but they cannot be separated or complementary (Nur, 2007) Islamic law in the sense of Islamic law is a system of rules based on the revelations of Allah SWT that is Qur'an and Hadith relating to the deeds of mukallaf, that is, people who have been able to be burdened with obligations and are binding on all of their servants. In principle, sharia contains ethical content, such as compassion, justice, virtue, and policies that lead to human welfare (Maulidi, 2015). Thus, if a servant wants his life to be prosperous, happy, peaceful, and safe in this world and the hereafter, then all the provisions of the law must be obeyed and implemented as they should be (Iryani, 2017).

Zakat is an Islamic teaching with the dimensions of worship and society. In the concept of Islam, paying zakat is not only seen as the obedience of a servant in carrying out the commands of Allah SWT but also to clean the property and receive blessings for sustenance (Dahlan, 2018). From an economic perspective, zakat can provide great use, especially for helping fellow Muslims as well as a means of fostering a better life. One of the mechanisms adopted in Sharia for collectivity obligations in the Muslim economy is the establishment of zakat institutions (Fitrah et al., 2017).

Sabiq, as quoted by Asnaini (2008), said that zakat is a designation of the right of Allah SWT, which must be issued to a Muslim who has the ability and up to the nisab for the poor. Furthermore, it is said why it is called zakat, because the zakat issued contains blessings and cleansing of the soul from the nature of stingy the rich 
and can avoid the envy of the poor and can create harmonious relationships as a form of solidarity. Another opinion states that zakat is one of the names of obligatory worship in Islam, which is carried out by giving one's property to people who are entitled to receive a certain amount according to the provisions of Islamic law(Sari, 2006).

Qardhawi, as quoted by Didin Hafidhuddin et al., explains that zakat as the main worship has a very important and strategic position both in aspects of Islamic teachings and aspects of developing the welfare of the people. To issue zakat means that someone has implemented the third of the five pillars of Islam so that its existence is automatically considered part of Islam (Triantini, 2015). From the aspect of the development of social welfare, zakat can overcome poverty, poverty, and economic injustice to realize social justice. This is the essence of zakat in the social dimension of Islamic teaching. Of course, this illustrates that Islam not only regulates matters of religious rituals but also pays attention to socio-economic problems that occur in society (Rahayu, 2018).

Furthermore, among the basic legal obligations for a Muslim to pay zakat is as in the translation of Surah Al-Baqarah verse 43 which reads "And establish prayer, perform zakat and bow down with those who bow down." Then, the translation of Surah At-Taubah verse 103, which reads "Take zakat from some of your property to clean and purify them and pray for them. Indeed, your prayers will be peace for them, and Allah is All-Hearing, All-Knowing' (Departemen Agama Republik Indonesia, 2008). Apart from the Qur'an, the obligation of zakat is also explained in the Hadith, one of the Hadith narrated by Imam Al-Buhari, Rasulullah SAW said "Whoever is blessed by Allah with wealth but does not fulfill his zakat, then on the Day of Judgment he will come a very scary and venomous bald snake with two spots on both eyes"(HR. Bukhari) (Fanani, 2014).

Based on the two basic laws above, namely the Qur'an and Hadith, the essence of the shari'ah is zakat, which builds the values of devotion to Allah SWT and creates a harmonious life for fellow human beings. Thus, the existence of zakat is an important pillar of Islam. This is based on the mention of zakat in the Qur'an which is always associated with prayer.

Zakat is an obligation for every Muslim who has the ability cannot be interpreted as a statement of goodness for muzakki, why so, because zakat, if understood as goodness, will make a sense of humility on the mustahik because he considers himself the hand below. Of course, such a view should not occur so that the purpose of zakat legislation to build and maintain the degree and dignity of humanity can be realized (Ministry of Religious Affairs of the Republic of Indonesia, 2013).

\subsection{The Existence of Zakat in The Law of Zakat Management}

As an instrument that aims to improve justice and public welfare, zakat in the context of a rule of law like Indonesia requires regulation in statutory regulation. This arrangement is expected to realize the implementation of good zakat management so that it can provide justice, benefits, and legal certainty.

In Indonesia, the regulation of zakat is regulated in Law Number 23 of 2011 concerning Amendments to Law Number 38 of 1999 concerning the Management 
of Zakat. General provisions of Law of the Republic of Indonesia Number 23 of 2011, Article 1 paragraph (2) confirms that zakat is an asset that must be issued by every Muslim or business entity to be given to the recipient following Islamic law. The law on zakat management also explains that the implementation of zakat management must be based on the principles or principles of Islamic law, mandate, benefit, justice, legal certainty, integration, and accountability. The implementation of zakat aims to increase the effectiveness and efficiency of services in managing zakat, as well as increasing the use of zakat to realize community welfare and poverty reduction (Aziz, 2017).

In addition to these laws, several regulations related to zakat include Government Regulation Number 14 of 2014 concerning Implementation of Law Number 23 of 2011 concerning Management of Zakat, Presidential Instruction Number3 of 2014 concerning Optimizing Zakat Collection in Institutions/Ministries, Secretariat General State Institutions, Secretariat General of State Commissions, Regional Governments, BUMN, and BUMD through the National Amil Agency and Presidential Decree of the Republic of Indonesia Number 27 of 2008 concerning Amendments to Presidential Decree of the Republic of Indonesia Number 8 of 2001 concerning National Amil Zakat Agency, and National Amil Zakat Agency Regulations Number 2 of 2014 concerning Guidelines for the Procedure of Providing Recommendations for the Establishment of the Amil Zakat Institution. Regulations regarding zakat are also contained in the Supreme Court Regulation of the Republic of Indonesia (2008) Number 2 of 2008 concerning Compilation of Sharia Economic Laws, to be precise in Article 668 to Article 684. The discussion includes the general provisions of zakat, assets that must be zakat, and the distribution of zakat. also specifically discussed zakat on mining goods and zakat in the profession. Zakat is the Islamic Economic Law Compilation (KHES), defined as an asset that must be issued by a Muslim or an institution owned by a Muslim to be given to the person entitled to receive it(Triantini, 2015).

In fact, some of the regulations described above can be said to be a form of formalization of Islamic law, which initially became unwritten law, now becomes written law so that it becomes a living, developing, and applicable law for Indonesian Muslims and its existence is recognized in the Indonesian legal system (Zarkasyi, 2015).The existence of the Zakat Management Law in the Indonesian legal system must also be understood as the direction of government legal policy to realize good zakat governance so that it can optimize the potential of national zakat, especially in fundraising, zakat utilization, and at the same time strengthening the implementation of zakat management and BAZNAS institutions. as a function of coordinating the management of zakat nationally (Bariyah, 2016).

The legal policy for the formation of the Zakat Management Law from the beginning was essentially an alternative in overcoming the problem of poverty in Indonesia, as implied in the preamble to the 1945 Constitution of the Republic of Indonesia, namely to advance public welfare (Rachim, 2018). Thus, the existence of zakat in the Zakat Management Law is an important pillar for improving the justice and welfare of society. This follows the preamble to the Zakat Management Law, which states that zakat is a religious institution that aims to improve the justice and welfare of the Indonesian people by taking into account the principles of equity, 
justice, and territoriality as the basis for implementation in zakat management (Januardi, 2018).

In the discourse of distributive justice, justice is a necessity that must be realized in people's lives so that there is no economic or social imbalance. One reason for economic inequality is not scarcity, but there is no balance or equity in economic distribution(Bariyah, 2013). According to Bagir Manan, realizing justice can only be done fairly. The fair mechanism is an element that includes mechanisms, time and predictive certainty, institutional certainty, and the certainty of rules (Manan, 2005).

In connection with the management of zakat, the principle of equity and justice requires that amil zakat in distributing zakat is not selective and right on target to everyone who has the right to receive zakat (mustahik), namely needy, poor, amil zakat, converts, riqab, gharim, fisabilillah, and ibnu sabil. In addition to having a sincere commitment to carrying out their duties and obligations accompanied by a sincere intention to provide excellent service to muzakki and mustahik so that they feel satisfied with the services provided (Bariyah, 2013). Therefore, zakat must be managed with good management based on Islamic law and applicable legal provisions in Indonesia. It should be understood that zakat management essentially refers to an institution that has the authority to plan, implement, and coordinate the collection, distribution, and utilization of zakat (Hasan, 2011).

\section{Law No. 23 of 2011 as an Ius Constitutum}

Judging from the history of its enactment, the Zakat Management Law in Indonesia is undergoing dynamic enactment along with the times and is also influenced by the dynamics of political and economic conditions. This fact can be seen from the management of zakat starting from the colonial period, post-independence, and reformation, which tends to show a different pattern. During the colonial period, zakat regulations were regulated in the Ordinance of the Dutch East Indies Government Number 6200, in which the Muslim community played a full role in managing zakat both by collecting and distributing it(Fathony, 2018). In this case, the government does not interfere with the management of zakat, but in practice, zakat management does not function effectively because the payment and distribution of zakat do not go well(Mukri Aji, 2014).

At the beginning of independence, the state began to be involved in zakat regulation; for example, the Ministry of Religion issued a Circular Number A / VII/17367 concerning the implementation of Zakat Fitrah, which, in essence, wanted the public to participate in supervising the distribution of zakat to comply with Islamic law. At the beginning of this independence, the management of zakat was sporadic and structurally not institutionalized. Furthermore, along with input from various parties, in 1968, the Minister of Religion issued two regulations at once, namely the Regulation of the Minister of Religion Number 4 of 1968 concerning the establishment of the Board Amil Zakat (BAZ) and Regulation of the Minister of Religion Number 5 of 1968 concerning the establishment of Baitul Mal. The establishment of the Baitul Mal as meant in the ministerial regulation functions as a recipient of zakat from muzakki and then submitted to the Agency Amil Zakat (BAZ). The impact of the issuance of these two ministerial regulations has encouraged the birth of several amil zakat institutions in Indonesia, such as the Al- 
Falah Social Fund Foundation in Surabaya and Dompet Dhuafa Republika in Jakarta.

Since post-reform, the government has increasingly shown its concern in managing zakat in Indonesia, as evidenced by the issuance of Law Number 38 of 1999 concerning Zakat Management, hereinafter referred to as the Law on Zakat Management. The purpose of this law is to establish a zakat institution in the context of reducing poverty in Indonesian legal regulations. However, in its implementation, Law No. 38 of 1999 is considered ineffective and has not been able to address problems in zakat management, such as in the case of zakat distribution that claimed lives in Pasuruan, East Java. This incident shows how weak the management of zakat management is not well organized, and on the other hand, the high poverty rate is still high, which has an impact on social inequality, which allows for horizontal conflicts in society (Herdianto, 2011).

Substantively, Law Number 38 Year 1999 regarding Zakat Management has several weaknesses and tends to be considered by some circles to hinder the development of zakat. This perspective is based on the absence of clear regulations regarding the separation between regulatory, supervisory, and implementation functions in managing zakat, so that it will have an impact on unhealthy zakat practices. The next weakness is from the sociological aspect, where in practice there are limited human resources for managing zakat, people's knowledge is still simple and traditional; therefore, in practice, zakat is only distributed directly by muzakki to neighbors who cannot afford or the Kiai who are liked, and the level is still low muzakki's belief that if zakat is submitted to amil zakat institutions, it is based on various phenomena of corruption, and so on.

Amil Zakat institutions that tend to compete to collect zakat funds and also tend to prioritize their organizations in poverty alleviation efforts have also become a problem in themselves, so the government issued a new law, namely Law Number 23 of 2011 and at the same time revoking Law Number 38 of 1999 concerning Zakat Management. The birth of the new Zakat Management Law is intended to improve the previous law because the old Zakat Management Law is deemed no longer following the development and needs of the community.

The passing of Law Number 23 of 2011 as an ius constitutum, which is the basis for the management of zakat, especially for Muslims and amil zakat in Indonesia. In the science of law, the Ius constitutum contains a meaning, namely the law currently in effect in a state territory(Syamsi, 2017). According to Soerjono Soekanto and Purnadi Purbacaraka, the ius constitutum is a positive law as opposed to the ius constituendum, namely the law that is aspired to interact with the life of the state but has not yet been formed into law or other regulations.

The point of difference between the ius constitutum and the ius constituendum lies on the time side, namely the present and the future. Soerjono Soekanto and Purnadi Purbacaraka also added that the change of ius constituendum to ius constitutum was among others by replacing laws with new laws that were previously drafted ius constituendum, amending existing laws by incorporating new elements that were previously ius constituendum, the development of a legal scholar's opinion or doctrine related to legal theory (Soekanto \& Purbacaraka, 1994). 
The enactment of the new Zakat Management Law has at least a fundamental change, especially in institutional principles. This can be seen in the preamble, which states that to increase the effectiveness and efficiency of zakat, it must be managed institutionally under Islamic law. Islamic law's meaning in this institutional principle implies that Islamic law is the principle in the management of zakat carried out by amil zakat, namely the National Amil Zakat Agency (BAZNAS) in terms of planning, collecting, distributing, and utilizing Zakat, alms, and other socio-religious funds (Bariyah, 2016).

The basis used in the management of zakat in both the old Zakat Management Law and the new Zakat Management Law are indeed not much different, meaning that there is still a relationship between religion and state. In the old Zakat Management Law, zakat management is based on faith, piety, openness, and legal certainty following Pancasila and the National Constitution of the Republic of Indonesia in 1945. Meanwhile, in the new Zakat Management Law, zakat management is based on Sharia Islam, trust, utility, justice, legal certainty, integration, and accountability. Similarly, the object of zakat is the same, but in the new Zakat Management Law, there is the addition of the object of zakat, which is another valuable letter (Article 4, paragraph (2) of Law Number 23 of 2011).

Although Law Number 23 Year 2011 regarding Zakat Management has been passed, this law has drawn various criticisms, especially by zakat activists. Several articles in Law Number 23 Year 2011 are considered unsustainable and contrary to the norms in society so that it will complicate and dwarf the community in collecting zakat and redistributing it to the less fortunate people around their environment. In addition, Law Number 23 Year 2011 is also considered by some circles to hinder the role and performance of existing zakat institutions. This is what underlies the Amil Zakat Institution to file a judicial review suit against Law Number 23 of 2011 to the Constitutional Court in August 2012. Through a long waiting process in October 2013, the Constitutional Court decided to reject most of the claims and granted only a small portion of the lawsuit submitted (Wibisono, 2015).

Under Law Number 23, 2011, zakat management seems to be a centralized government through the National Amil Zakat Agency (BAZNAS) so that it triggers doubts and distrust that this institution can carry out its functions properly considering its low human resources and the bureaucratic system. weak and the phenomenon of corruption that is quite high in this country is a separate concern for zakat activists, where zakat is a manifestation of the obedience of a servant in carrying out the law that will be misused, which in the end does not follow the stated objectives of zakat in Islam and Law Number 23 of 2011 concerning the Management of Zakat.

Regardless of the above controversy, Law Number 23 Year 2011 is a positive law in effect in Indonesia even though the law is not compelling because there is no legal sanction for compulsory zakat. However, to realize the effectiveness of its implementation, legal awareness of all parties is needed to comply with it to achieve legal ideals, namely the realization of justice, benefit, and legal certainty. Thus, social justice and social welfare, especially for the needy and the poor, will be realized. 


\section{The Integration of Islamic Law in The Law of Zakat Management}

The legal policy of Law Number 23 Year 2011 concerning Zakat Management is a form of the state's role as a regulator and facilitator that aims to make the implementation of zakat management more transparent and professional. At the level of implementation, zakat management in Indonesia is carried out by zakat management institutions, namely the National Amil Zakat Agency (BAZNAS), which is domiciled in the capital city of the state, province, district/city, and is carried out by the Amil Zakat Institution (LAZ), which is formed by a social organization after obtaining a permit. Minister or official appointed by the minister. In this case, the role of the state cannot be ignored in the management of zakat. Nasaruddin Umar said that ignoring the role of the state is against the principles of sharia, which requires order and legal certainty(Baiquni, 2012).

The birth of the Zakat Management Law is also based on the paradigm that the government responds to the wishes of the Muslim community who want zakat regulation, which is manifested in statutory regulations as a positive law considering that Indonesia is the majority of the population is Muslim, so ideally zakat can be an instrument to alleviate poverty (Safitri, 2017). In addition, the birth of the Zakat Management Law can also be said to be a form of foresight by the government in seeing the huge amount of zakat potential at a macro level; if it can be maximized, it will be a strength and solution for improving the country's economy and as economic empowerment to elevate the dignity of the needy and poor (Ministry of Religious Affairs of the Republic of Indonesia, 2013).

The great economic and social potential, as described above, ultimately prompted the government to issue Law Number 38 of 1999 concerning Zakat Management, which was further revised by Law Number 23 of 2011 concerning Zakat Management. It should be emphasized that the purpose of issuing this Zakat Management Law is to improve the welfare of the community following the state objectives stated in the preamble to the 1945 Constitution of the Republic of Indonesia, namely advancing public welfare in the framework of the concept of national development and a welfare state (Rachim, 2018).

The existence of the law on zakat management in the context of a rule of law must be understood as an attempt by the state to maximize its role in realizing the potential of zakat owned by Muslims. Although it is realized that the Zakat Management Act has not fully accommodated the interests or aspirations of Muslims. However, one of the interesting things from Law No. 23 of 2011 concerning zakat management is that it places Islamic law as the basis for zakat management even though Indonesia is not an Islamic state, implying that zakat as a basic norm regulated in law is essentially the realm of religion as regulated in Islamic law (Suprima \& Rahman, 2019).

Management of zakat based on the principles of Islamic law is one of the important keys of the Zakat Management Act and must be understood and implemented by amil zakat. The zakat that has been collected requires distribution and utilization following Sharia principles. To distribute and utilize zakat, amil must carry out the principle of justice, meaning that the collected zakat must be immediately distributed to people who are truly entitled to receive it (mustahik).which, in its fulfillment, does not exceed the level of need. The definition of fair here is not based 
on the same measure but to safeguard people's benefits of the people (Fitrah et al., 2017).

Bariyah (2013) in his article entitled "Sharia Principles in Zakat Management" says that zakat justice in human life is something that must be realized so that economic and social inequality does not occur.The occurrence of inequality does not occur due to scarcity but is due to the allocation of economic resources and unequal distribution. According to the principle of justice, the distribution of zakat can realize a balanced situation, namely, the realization of an equal distribution of wealth to the poor. Therefore, Islam places justice as an important and universal teaching that must be implemented by every Muslim in his life activities.

In essence, implementing the principle of justice in distributing zakat is the same as carrying out the main mission of Islam, namely rahmatan lil alamin. Justice must be upheld because, with justice, economic and social disparities will be eliminated and can even have a major impact on the balance of the national economy, which will have implications for improving the welfare and prosperity of the community, which is in line with the objectives of zakat management as stipulated in Article 3 of Law Number 23 Year 2011 concerning Zakat Management.

In addition to the principle of justice, amil zakat in distributing zakat must also apply the principle of equity. Although this principle is not explained in detail in Law Number 23 of 2011, the principle of equalization can be interpreted as follows: in distributing amil zakat, it must pay attention to aspects of its equal value, both related to nominal and economic welfare for mustahik. The aim is to realize income distribution and social justice for citizens in need.Sulton Hanafi in Latif (2018) says that the principle of equity is the distribution of zakat evenly to eight (8) asnaf by paying attention to priority scales and based on justice objectives. This means that the distribution of zakat according to the principle of equal distribution is not a distribution by distributing zakat funds evenly based on nominal, but rather the equal distribution of zakat to asnaf, which is based on individual needs.

According to Yusuf Qardhawi, as quoted by Narulira (2005), in the context of justice and equity in the distribution of zakat, zakat managers, in this case, amil zakat, must pay attention to several principles, including 1) if the zakat collected is large, then each group Asnaf receives a portion according to their needs, respectively; 2) it is permissible to give all parts to several asnaf groups if it is found that a need from that group requires special handling; 3 ) prioritizing the needy and poor as recipients of zakat so that they can fulfill their daily needs and do not depend on other groups because this is the purpose of zakat in Islam.

The distribution of zakat is closely related to efforts to realize the function of zakat as social security for mustahik who are entitled to receive zakat. Begging and begging are acts that are prohibited by Islam; therefore, amil zakat is required to play an active role in finding the mustahik who needs it. Scholars agree that the needy and the poor are mustahik groups that must be prioritized because the purpose of zakat management is to improve welfare and alleviate poverty among Muslims (Hafidhuddin et al., 2015).

In the implementation of the distribution and utilization of zakat, amil zakat must also pay attention to regional principles, namely that zakat collected in an area must be given to those entitled to receive (mustahik) in that area. Zakat collected at zakat 
management institutions must also be distributed entirely within one year. According to Sharia principles, the management of zakat is essentially not familiar with a centralized system in the sense that zakat collected from various regions is collected centrally to the center (Hafidhuddin et al., 2015).

The management of zakat following Islamic law as described above is an integral part of the preamble and mandate of Article 2 of Law Number 23, 2011, so that it can be understood as a form of sharia integration in the Zakat Management Act. This is also confirmed in Article 25 (2011), which states that zakat must be distributed to mustahik following Islamic law. Article 26 (2011) states that the distribution of zakat is carried out based on a priority scale by considering the principle of equity, the principle of justice, and the principle of territoriality.

\section{CONCLUSION}

The results of this study indicate that the existence of zakat in Islamic law and the law of zakat management (Law No. 23 of 2011 on Zakat Management) places zakat as an important pillar in building the values of devotion to Allah SWT and realizing justice and community welfare so that it will manifest a harmonious life with others. Law No. 23, 2011, as well as revoking Law No. 38 of 1999 on Zakat Management is an inseparable part of the laws and regulations in Indonesia and has become the law of zakat management currently in effect in Indonesia (ius constitutum). The integration of Islamic law in zakat management's law is reflected in the considerations and substance of Article 2 of Law No. 23 of 2011 on Zakat Management, which places Islamic law as a principle in zakat management, in addition to the principles of trust, benefit, justice, legal certainty, integration, and accountability. which in the previous law of zakat management was not stated.

\section{REFERENCES}

\section{Books}

Amiruddin, \& Asikin, Z. (2012). Introduction to Legal Research Methods. Raja Grafindo Persada.

Ash-Shiddieqy, T. M. H. (2009). Zakat Guidelines (Ketiga). Pustaka Rizki Putra. Asnaini. (2008). Productive Zakat in Islamic Law Perspective. Pustaka Pelajar.

Departemen Agama Republik Indonesia. (2008). Al-Qur'an and its Translation. Toha Putra.

Hafidhuddin, D., Nasar, F., Kustiawan, T., Beik, I. S., \& Hakiem, H. (2015). Indonesian Zakat Fiqh (Mold I). Badan Amil Zakat Nasional (BAZNAS).

Khadziq. (2009). Islam and Local Culture: Learning to Understand the Reality of Religion in Society (Cet. 1). Teras.

Hasan, M. (2011). Effective Management Model Zakat Management. Idea Press. Lexi J, M. (2002). Metodologi Penelitian Kualitatif. Remaja Rosdakarya. Manan, B. (2005). An Authorized Justice System: A Quest. Fakultas Hukum UII. Mochlasin. (2014). Management of Zakat and Waqf in Indonesia (Mold I). STAIN Salatiga Press.

Sari, E. K. (2006). Introduction to the Law of Zakat and Waqf. Grasindo.

Narulira, S. (2005). The spectrum of Zakat in Developing a Citizenship Economy. Zikrul Hakim. 
Nur, S. (2007). Fiqh: A Comprehensive Introduction to Islamic Law. Tafakur.

Soekanto, S., \& Purbacaraka, P. (1994). Various Ways of Legal Differentiation. Citra Aditya Bakti.

Ministry of Religious Affairs of the Republic of Indonesia. (2013). Practical Zakat Guide. Ministry of Religious Affairs of the Republic of Indonesia.

Wibisono, Y. (2015). Managing Indonesian Zakat: Discussion on National Zakat Management from the Regime of Law Number 38 of 1999 to the Regime of Law Number 23 of 2011 (First Edit). Prenadamedia Group. https://books.google.co.id/books?hl=en\&lr=\&id=uBVNDwAAQBAJ\&oi=fn $\mathrm{d} \& \mathrm{pg}=\mathrm{PA} 77 \& \mathrm{dq}=$ politik+hukum+undangundang+pengelolaan+zakat\&ots=1nag3W9swq\&sig=OLowi371PINzolAWFI ebIRbPVVQ\&redir_esc $=\mathrm{y} \# \mathrm{v}=$ onepage $\& \mathrm{q}=$ politik hukum undang-undang pengelolaan zakat $\& \mathrm{f}=\mathrm{false}$

\section{Journal}

Aziz, M. (2017). Strategies for Productive Zakat Management at Amil Zakat Institutions in the Review of Law of the Republic of Indonesia Number 23 of 2011 concerning Zakat Management (Case Study at Nurul Hayat Tuban Branch Office 2015-2016). AL HIKMAH: Journal of Islamic Studies, 7(1), 127.

Bariyah, O. N. (2013). Sharia Principles in Zakat Management by Zakat Management Institutions. Nuansa Journal: Actualization of Islamic and Social Studies, 6(1), 51-61.

Bariyah, O. N. (2016). Dynamics of Legal Aspects of Zakat and Waqf in Indonesia. AHKAM: Journal of Sharia Sciences, 16(2), 197-212. https://doi.org/10.15408/ajis.v16i2.4450

Canggih, C., Fikriyah, K., \& Yasin, A. (2017). Potential and Realization of Indonesia's Zakat Fund. Al-Uqud: Journal of Islamic Economics, 1(1), 14. https://doi.org/10.26740/al-uqud.v1n1.p14-26

Dahlan, D. (2018). Zakat Bank: Zakat Management with the Concept of a Social Bank Based on the Principles of Sharia. Journal of Islamic Economics and Business, 4(2), 156. https://doi.org/10.20473/jebis.v4i2.10720

Fanani, A. M. dan B. (2014). National Zakat Fund Collection (Potential, Realization, and Important Role of Zakat Management Organizations). Journal Permana, 5(2), 7-16.

Fathony, A. (2018). Optimizing the Role and Function of the Amil Zakat Institution in Carrying Out Social Functions. Journal Hakam, 02(01), 1-32.

Fitrah, I., Triyuwono, I., \& Adib, N. (2017). Good Governance Principles in Zakat Management in Qardhawi Perspective: A Study at Baitul Mal Aceh Tengah District. Jurisdiction: Journal of Law and Sharia, 8(1), 21-44. https://doi.org/10.18860/j.v7i3.4318

Hafriza, R. H., Firdaus, \& Chuzairi, A. (2018). Management of Zakat as Balancing the Economy of the People. Journal of Perada, 1(1), 45-58. http://ejournal.stainkepri.ac.id/index.php/perada

Herdianto, A. W. (2011). The Role of the State in Optimizing Zakat in Indonesia. Jurisdiction, Journal Law and Shariah, 2(1), 103-116.

Indonesian Supreme Court Rules. (2008). Indonesian Supreme Court Regulation 
No. 2 of 2008 concerning Sharia Economy Law Compilation.

Iryani, E. (2017). Islamic Law, Democracy and Human Rights. Journal Ilmiah Universitas Batanghari Jambi, 17(2), 24-31.

Januardi. (2018). Zakat in a Positive Legal Perspective of Indonesia. Journal of Islamic Society and Philanthropy, 1(1), 9-11. https://doi.org/10.36769/asy.v20i1.43

Maulidi. (2015). Maqasid Syariah as the Philosophy of Islamic Law: A Systematic Approach According to Jasser Auda. Journal Al-Mazahib, 3(1), 1-19.

Mukri Aji, A. (2014). Optimizing the Strategic Role of Amil Zakat in the Perspective of Islamic Law and Indonesian Positive Law. SALAM; Journal of Philosophy and Legal Culture, 1(1). https://doi.org/10.15408/sjsbs.v1i1.1523

Puspitasari, R. D., \& Darma, E. S. (2019). The Influence of Sharia Governance Implementation on Muzakki's Satisfaction and Loyalty (Study at Amil Zakat Institution in DIY). Journal of Accounting Review and Indonesian Business, 3(1), 67-84. https://doi.org/10.18196/rab.030137

Rachim, H. A. (2018). Social Policy for Zakat, Parameters for the Development of Welfare State Indonesia. Journal of Society and Islamic Philanthropy, 1(1), 16. http://jurnal.unpad.ac.id/jmfi/article/view/19197/8946

Rahayu, S. S. (2018). Law of Application of Transparency Principles in Zakat Managemen. Mutawasith: Journal of Islamic Law, 1(1), 19-34.

Safitri, J. (2017). Implementation of the Concept of Zakat in the Qur'an as an Effort to Alleviate Poverty in Indonesia. Journal of At-Tasyri, IX(1), 1-15.

Suprima, \& Rahman, H. (2019). Regulation of Zakat Management in Indonesia. Journal of Juridical, 6(1), 132-146. https://doi.org/10.35586/jyur.v6i1.873

Syamsi, A. B. (2017). Transformation of Islamic Economic Law as Ius Constituendum into Ius Constitutum. Et-Tijarie: Journal of Sharia Law and Business, 4(1), 1-16.

Triantini, Z. E. (2015). The urgency of Zakat Regulation in Economic Growth in Indonesia. Istinbath, Journal of Islamic Law, 14(1), 85-99.

Yurista, D. Y. (2017). The Principle of Justice in Tax and Zakat Obligations According to Yusuf Qardhawi. Ulul Albab: Journal of Islamic Law Studies and Research, 1(1), 39. https://doi.org/10.30659/jua.v1i1.1962

Zarkasyi, A. (2015). Integrating the Role of IQ, EQ, and SQ in Islamic Law Regulation. Journal Qolamuna, 1(1), 223-244.

\section{Theses, Dissertations, and Others}

Latif, A. (2018). Implementation of the Principles of Equity, Justice, and Territoriality in the Distribution of Zakat Based on Law Number 23 the Year 2011 concerning Zakat Management (Study at the National Zakat Board of Malang City). In Central Library. Universitas Islam Negeri Maulana Malik Ibrahim Malang.

Baiquni. (2012). Government: The management of Zakat must be regulated by the state. Merdeka.Com. https://www.merdeka.com/peristiwa/pemerintahpengelolaan-zakat-harus-diatur-negara.html

\section{Law and Regulation}

The 1945 Constitution of the Republic of Indonesia 
Aristoni : The Integration of Islamic Law in The Law of Zakat Management | 33

Law of the Republic of Indonesia Number 12 of 211 concerning the Formation of Legislative Regulations

Law of the Republic of Indonesia Number 23 of 2011 concerning Amendments to Law Number 38 of 1999 concerning Management of Zakat

Regulation of the Supreme Court of the Republic of Indonesia Number 2 of 2008 concerning Compilation of Sharia Economic Law 